\title{
Modeling of Dynamic Ammonia Concentrations in Two Commercial Layer Hen Houses
}

\author{
S. Liu, J. Q. Ni*, A. J. Heber, and W. Z. Liang \\ Department of Agricultural and Biological Engineering, Purdue University, West Lafayette, IN 47907, USA
}

Received March 3, 2015; revised November 5, 2015; accepted December 3, 2015; published online March 14, 2017

\begin{abstract}
Ammonia $\left(\mathrm{NH}_{3}\right)$ concentrations in confined layer hen houses are the highest among buildings of different animal species and are of great concern to indoor air quality and animal welfare. However, little has been done to investigate the dynamic relationships between $\mathrm{NH}_{3}$ concentrations and the influencing factors. A Distributed Lag Non-linear Model was applied to study the dynamics of $\mathrm{NH}_{3}$ in two high-rise layer houses using a two-year dataset, compiled with hourly data, and its two subsets of summer and winter. Three major influencing factors, the ventilation rate, outdoor temperature, and outdoor relative humidity, were identified to have lagged effects on indoor $\mathrm{NH}_{3}$ concentrations in both houses. The duration of lagged effects of ventilation rate ranged from non-observable $(<1 \mathrm{~h})$ to a few subsequent hours. However, in winter, the changes in ventilation rates within the low operational ranges were not sufficiently high to induce $\mathrm{NH}_{3}$ concentration changes. The effects of temperature were not observable in winter. Higher outdoor relative humidity was related to elevated $\mathrm{NH}_{3}$ concentrations in winter, with a lag time of about $1 \mathrm{~h}$ in both houses. The lagged effects were considerably different between summer and winter for all three influencing factors.
\end{abstract}

Keywords: air quality, ammonia pollution, animal agriculture, environmental modeling, poultry house

\section{Introduction}

Ammonia $\left(\mathrm{NH}_{3}\right)$ is a primary air pollutant in poultry houses and is released from manure. Poultry are commonly fed high-protein diets that exceed their nutritional requirements. Consequently, undigested proteins and uric acid remaining in the manure become the main sources of decomposition and $\mathrm{NH}_{3}$ generation, accounting for $30 \%$ and $70 \%$ of the excreted nitrogen, respectively (Groot Koerkamp, 1994).

As the most abundant alkaline gas in the atmosphere, $\mathrm{NH}_{3}$ plays an important role in atmospheric chemistry. When an excess amount is emitted into the atmosphere, $\mathrm{NH}_{3}$ can be a precursor to aerial nitrous oxide $\left(\mathrm{N}_{2} \mathrm{O}\right)$ and secondary particles (Hallquist et al., 2009; Behera et al., 2013), contributing to both the formation of aerosol and to global climate change. Acidification of soil could also occur due to wet and dry $\mathrm{NH}_{3}$ deposition. An unexpected high level of $\mathrm{NH}_{3}$ in the environment can reduce the living quality of the community and lead to complaints of odors from the residents. Therefore, attempts have been made to model the dispersion of $\mathrm{NH}_{3}$ from agricultural sources (Theobald et al., 2012; Blanes-Vidal et al., 2012).

High indoor $\mathrm{NH}_{3}$ concentrations in livestock and poultry houses have aroused worldwide concerns because of the adver-

${ }^{*}$ Corresponding author. Tel.: +1 7654961733; Fax: +17654961115.

E-mail address: jiqin@purdue.edu (J. Q. Ni)

ISSN: $1726-2135$ print/1684-8799 online

(C) 2016 ISEIS All rights reserved. doi:10.3808/jei.201700360 se consequences they cause in occupational health and livestock welfare (Kristensen and Wathes, 2000). Miles et al. (2004 ) and Wei et al. (2014) experimentally confirmed that exposure to $\mathrm{NH}_{3}$ resulted in declined body weight, decreased muscle antioxidative capacity, as well as increased mortality of broilers. Xin et al. (2011) reviewed and summarized the hazardous effects of excessively high $\mathrm{NH}_{3}$ concentrations in poultry houses, including reduced growth rate, decreased egg production, damaged respiratory tract, and reduced egg quality. Limiting indoor $\mathrm{NH}_{3}$ concentrations in poultry houses is also necessary because birds are sensitive animals that need a precisely controlled indoor climate (Dawkins et al., 2004). Preventing these adverse effects require quick responses and actions for pollutant control.

The 15-min and 8-h exposure limits for gaseous $\mathrm{NH}_{3}$ for workers are $35 \mathrm{ppm}$ and $25 \mathrm{ppm}$, respectively, as recommended by the National Institute for Occupational Safety and Health (OSHA). Poultry houses are reported to have the highest indoor $\mathrm{NH}_{3}$ concentrations and emissions among different livestock and poultry species, and often exceed the recommended levels (Wathes et al., 1998; Groot Koerkamp et al., 1998). Ni et al. (2012) found that the 2-year mean $\mathrm{NH}_{3}$ concentrations at ventilation fans of two hen houses of high-rise design at deep manure pit level were 48.9 and $51.9 \mathrm{ppm}$, and those of two houses of manure belt design at cage level were 13.3 and $12.9 \mathrm{ppm}$. The maximum daily mean $\mathrm{NH}_{3}$ concentrations at the manure pit ventilation fans reached $180 \mathrm{ppm}$ in the high-rise houses ( $\mathrm{Ni}$ et al., 2012). Although caged hens were not exposed to the air in manure pits, manure pits were still working area. Approximately $70 \%$ of laying hen houses were high-rise design and the re- 
maining 30\% were manure belt system in the United States (Xin et al., 2011). Therefore, high $\mathrm{NH}_{3}$ concentrations in highrise layer houses are a great concern.

Concentrations of $\mathrm{NH}_{3}$ in a poultry house result from a dynamic balance between the $\mathrm{NH}_{3}$ released from manure in the house and the $\mathrm{NH}_{3}$ exhausted out of the house to the outdoor environment. The release of $\mathrm{NH}_{3}$ is controlled by a variety of factors affecting the manure status and micro-climate above the manure surface. The emission of $\mathrm{NH}_{3}$ is determined by the $\mathrm{NH}_{3}$ concentration and the ventilation rate, which are usually following the changes in outdoor weather conditions (Groot Koerkamp, 1994; 1998).

It has been known that $\mathrm{NH}_{3}$ concentrations in poultry houses vary over the time of the day and the seasons of the year (Liang et al., 2005; Ni et al., 2012; Lin et al., 2012; Wang Li et al., 2013). Moreover, rapid changes in weather conditions and house management can cause sudden changes in indoor $\mathrm{NH}_{3}$ concentrations. Therefore, large dataset collected from field monitoring with high time resolution and sufficiently long duration to include a variety of outdoor environment and farm operational conditions are needed to facilitate the research on $\mathrm{NH}_{3}$ dynamics and their interactions with other factors. While the existing knowledge and models for air quality in animal agriculture are still very limited, comprehensive field monitoring datasets are generally far from being fully analyzed. Information contained in the datasets is still waiting to be exploited and turned into knowledge. This remains a research gap that is urgently needed to fill (Ni et al., 2011).

The National Air Emissions Monitoring Study (NAEMS) was carried out to collect data of selected air pollutants, including $\mathrm{NH}_{3}$, from 38 livestock and poultry houses in the U.S. from 2007 to 2009 (Heber et al., 2008). A large database after two years of continuous air quality monitoring was generated, providing possibilities for dynamic $\mathrm{NH}_{3}$ concentration modeling in layer houses. The monitoring at the IN2H site supplied one of the most comprehensive datasets among all NAEMS sites, representing a typical farm with high-rise layer houses in the Midwest region of the U.S.

Several data analysis methods have been applied to existing databases. Traditional statistical methods and new data mining technologies have been used to predict the emissions from animal barns (Liang et al., 2005; Nimmermark and Gustafsson, 2005; Wheeler et al., 2006; Sun and Hoff, 2010; Lin et al., 2012). However, all these methods exhibited limited capability in describing complex processes in the animal buildings because the relationships between the $\mathrm{NH}_{3}$ concentrations and the influencing factors are neither static nor limited to the moment of observation. There were methods proposed for dynamic environmental simulation and prediction (Huang et al., 2004; Battista and Visini, 2006), but very few have been applied in the field of agricultural air quality. Bjerg et al. (2013) studied the perspectives of modeling spatially and temporally the distributed indoor conditions around $\mathrm{NH}_{3}$ release surfaces, calling for more efforts devoted to dynamical modeling of $\mathrm{NH}_{3}$ in animal houses.

The Distributed Lag Model (DLM) was previously used to analyze the effects of air pollutants on human health, in which the time lags of several days between air pollution events and local mortalities were of substantial concern (Schwartz, 2000; Zanobetti et al., 2000). The Distributed Lag Non-linear Model (DLNM), which was briefly introduced by Armstrong et al. (2006), is a development of DLM. The implementation procedures of the DLNM in the package "dlnm" for the statistical software R was described by Gasparrini et al. (2010) in detail. The DLNM is a powerful and flexible tool, capable of characterizing non-linear relationships along both the space of the predictor and that of time. It has already been applied to study the delayed effects of air pollutants either on the risk of local mortality or the occurrence of a specific disease (Guo et al., 2010; 2011; Wu et al., 2013). However, this modeling technique has not yet been applied to the study of agricultural air quality.

The objective of this paper is to mine an existing dataset and gain insight into the non-linear lagged relationships between $\mathrm{NH}_{3}$ concentrations and the major influencing factors, including ventilation rate, outdoor temperature $(\mathrm{T})$, and outside relative humidity $(\mathrm{RH})$, in high-rise layer houses by using the DLNM. The results and conclusions are expected to help interpret the physical phenomenon and understand the dynamics related to $\mathrm{NH}_{3}$ in the high-rise layer houses, and provide information for improving farm management in the future.

\section{Materials and Methods}

\subsection{The Dataset}

An air quality monitoring dataset was acquired by the NAEMS at the IN2H site that consisted of two high-rise layer houses in Indiana. The final report of the IN2H site monitoring and average daily mean data were publically accessible in the U.S. EPA website (USEPA, 2010). However, the NAEMS' recorded raw data had 1-min time resolution. In this study, the 1min monitoring data were averaged to 1-hour mean data and used to develop the DLNM model.

\subsubsection{Characteristics of the High-Rise Layer Houses}

The IN2H monitoring site consisted of two high-rise layer houses designated here as $\mathrm{H}-\mathrm{A}$ and $\mathrm{H}-\mathrm{B}$, which were constructed in 1997 with a capacity of 250,000 birds in each house. The length of the house was $198.0 \mathrm{~m}$ and the width was 30.5 $\mathrm{m}$. Detailed descriptions of the houses were provided in $\mathrm{Ni}$ et al. (2012). Layer hens were raised in rows of five-tier A-frame cages at the second floor. Hen manure dropped off slanted boards underneath the cages, and accumulated in a $2.5-\mathrm{m}$ high first floor, or manure pit, for more than one year before being removed.

Outdoor air entered into the second floor from the attic through three temperature-adjusted V-shaped baffled ceiling air inlets and exited the house from 1.2-m diameter belted fans (Model AT481Z1CP, Aerotech Inc., Mason, MI, USA), distributed along the east and west side wall of the manure pit in each house. Among the 55 pit fans on each side wall, 5 were variable speed fans as the first ventilation stage and the remainning 50 were single-speed fans assigned to 12 other ventilation stages. House ventilation rates were computer-controlled based 
on the house temperature requirement and the actual house temperatures that were measured with 12 temperature sensors distributed equally on the second floor. Lights on the second floor were turned off for $8 \mathrm{~h}$ each night approximately between 8:00 PM - 4:00 AM.

\subsubsection{Characteristics of Data Collection}

Ammonia concentrations were measured in the air that was sampled at $5 \mathrm{~L} \mathrm{~min}^{-1}$ from 15 Gas Sampling Locations (GSL) in the two houses. Twelve of the GSL were installed at the inlets of 12 variable-speed pit fans (Fans 6, 27, and 49 in each side wall) in the two houses. One GSL was installed at the roof top of H-B to take incoming outdoor air samples. Two other GSL, one in each house, were installed in the attics at the $\mathrm{V}$-shaped air inlets. Air was sampled for $20 \mathrm{~min}$ at the first air inlet location and then sequenced through all the other GSL for $10 \mathrm{~min}$ at each GSL. Air sampling lasted for $90 \mathrm{~min}$ in $\mathrm{H}-\mathrm{A}$ and 70-min in H-B.

Sampled air was transported through Teflon tubing from each GSL to a Gas Sampling System (GSS). Ammonia concentrations in the sample air from the GSS were measured continuously using a photoacoustic infrared multi-gas monitor (Innova Model 1412, LumaSense Technologies, Ballerup, Denmark), located in an on-farm instrument shelter (OFIS) between the two houses. In addition to weekly precision checks using certified zero air and $\mathrm{NH}_{3}$ gas, multi-point calibrations were conducted periodically to ensure linearity of the instrument.

Outdoor RH and temperature were measured using a shielded capacitance-type $\mathrm{RH}$ and temperature $(\mathrm{RH} / \mathrm{T})$ probe (Mo- del RHT-WM, Novus Automation, Porto Alegre, Brazil). Air $\mathrm{RH}$ and temperature in the manure pits were monitored with two RH/T probes, located at fans south 27 in H-A and north 27 in H-B. Thermocouples (T-type) were used for temperature measurements at all GSL.

Layer hen inventories and mortalities were recorded manually on a daily basis by the producer and provided to the researchers on weekly data sheets. Hen densities in the houses were calculated by dividing the total live mass of the hens in the house by the house cage floor area of $6039 \mathrm{~m}^{2}$. Infrared activity sensors (Visonic SRN 2000 Detector, Visonic Inc., Bloomfield, CT, USA) were mounted to walls or support posts in the houses to monitor movements of birds and workers. Manure accumulation in the pits was calculated using the annual and biennium manure load-out weights and the layer hen inventories. The manure load-outs from the pits were the sums of individual truckloads of manure weighed with a truck scale and provided by the producer. Additional descriptions of the data collection are provided by $\mathrm{Ni}$ et al. (2012).

\subsubsection{General Statistics of the Dataset}

To facilitate the dynamic modeling, the dataset was grouped into several subsets, including two seasonal subsets. The "summer" subset included data from June 1 to August 31; and the "winter" subset included data from December 1 to the end of February. The statistics presented in Table 1 were obtained for all valid hourly data to maximize the data size. This method of data selection was different from the "valid data days", which were defined as $>75 \%$ or $>16$ hours of valid data during the day and used in previous publications (Ni et al., 2010; 2012).

Table 1. Statistics of Selected Parameters of the Hourly Dataset

\begin{tabular}{|c|c|c|c|c|c|c|c|c|c|c|c|c|c|}
\hline \multirow{2}{*}{ Parameter } & \multirow{2}{*}{ House } & \multicolumn{4}{|c|}{ Two years } & \multicolumn{4}{|c|}{ Summer * } & \multicolumn{3}{|c|}{ Winter * } & \multirow[b]{2}{*}{ Mean \pm Std } \\
\hline & & $\mathrm{n}$ & Max & Min & Mean \pm Std & $\mathrm{n}$ & $\operatorname{Max}$ & Min & Mean \pm Std & $\mathrm{n}$ & $\operatorname{Max}$ & Min & \\
\hline Ammonia & $\mathrm{H}-\mathrm{A}$ & 15,757 & 217.4 & 0.0 & $48.9 \pm 40.6$ & 3990 & 41.6 & 0.0 & $10.6 \pm 6.2$ & 3883 & 217.4 & 51.7 & $102.7 \pm 24.7$ \\
\hline (ppm) & H-B & 15,808 & 226.8 & 0.2 & $52.0 \pm 41.8$ & 3938 & 53.0 & 0.2 & $10.7 \pm 8.0$ & 3871 & 226.8 & 42.9 & $103.9 \pm 29.3$ \\
\hline Ventilation & $\mathrm{H}-\mathrm{A}$ & 15,935 & 723.9 & 12.7 & $183.2 \pm 195.3$ & 4166 & 723.9 & 61.5 & $397.8 \pm 212.3$ & 3969 & 164.1 & 24.1 & $49.0 \pm 13.1$ \\
\hline$\left(\mathrm{m}^{3} \mathrm{~s}^{-1}\right)$ & H-B & 15,898 & 731.2 & 20.0 & $200.0 \pm 209.1$ & 4077 & 731.2 & 59.9 & $421.6 \pm 214.5$ & 3571 & 186.0 & 20.0 & $52.2 \pm 18.2$ \\
\hline $\begin{array}{l}\text { Outdoor T } \\
\left({ }^{\circ} \mathrm{C}\right)\end{array}$ & & 16,980 & 34.8 & -22.8 & $12.3 \pm 11.8$ & 4284 & 34.7 & 11.3 & $24.6 \pm 4.3$ & 4099 & 19.7 & -22.8 & $-1.8 \pm 6.5$ \\
\hline Cage T & $\mathrm{H}-\mathrm{A}$ & 16,980 & 34.0 & 7.5 & $27.5 \pm 2.8$ & 4284 & 34.0 & 17.3 & $28.0 \pm 2.3$ & 4099 & 32.5 & 12.0 & $28.0 \pm 2.4$ \\
\hline$\left({ }^{\circ} \mathrm{C}\right)$ & H-B & 16,980 & 34.0 & 12.4 & $25.8 \pm 2.6$ & 4284 & 34.4 & 18.4 & $27.2 \pm 2.5$ & 4087 & 30.4 & 12.4 & $25.7 \pm 2.3$ \\
\hline Exhaust T & $\mathrm{H}-\mathrm{A}$ & 16,980 & 34.1 & 5.8 & $26.2 \pm 2.7$ & 4284 & 34.1 & 19.5 & $26.2 \pm 2.7$ & 4099 & 27.0 & 5.8 & $18.8 \pm 2.4$ \\
\hline$\left({ }^{\circ} \mathrm{C}\right)$ & H-B & 16,980 & 34.4 & 5.6 & $26.2 \pm 2.7$ & 4284 & 34.4 & 17.9 & $26.2 \pm 3.0$ & 4099 & 27.1 & 5.6 & $18.5 \pm 2.7$ \\
\hline $\begin{array}{l}\text { Outdoor RH } \\
(\%)\end{array}$ & & 16,453 & 99.9 & 14.3 & $68.5 \pm 18.2$ & 4286 & 98.4 & 21.9 & $62.1 \pm 16.6$ & 3667 & 99.8 & 48.3 & $82.8 \pm 10.5$ \\
\hline Cage RH & H-A & 16,980 & 70.9 & 23.7 & $48.8 \pm 6.8$ & 4283 & 70.9 & 27.5 & $50.0 \pm 8.6$ & 4099 & 65.5 & 42.3 & $50.7 \pm 3.0$ \\
\hline$(\%)$ & H-B & 16,980 & 69.6 & 21.0 & $51.6 \pm 7.6$ & 4284 & 69.6 & 26.0 & $50.4 \pm 9.0$ & 4087 & 67.0 & 44.4 & $56.7 \pm 3.9$ \\
\hline Exhaust RH & $\mathrm{H}-\mathrm{A}$ & 16,988 & 83.8 & 16.9 & $51.9 \pm 10.6$ & 4283 & 83.8 & 22.8 & $54.1 \pm 13.0$ & 4099 & 81.7 & 45.0 & $57.7 \pm 5.6$ \\
\hline$(\%)$ & H-B & 15,784 & 88.9 & 16.8 & $52.9 \pm 11.5$ & 4283 & 78.0 & 21.4 & $51.8 \pm 11.9$ & 2895 & 88.9 & 30.2 & $62.6 \pm 10.6$ \\
\hline Live mass & H-A & 17,349 & 57.5 & 8.05 & $52.4 \pm 3.6$ & 4416 & 57.5 & 48.9 & $54.4 \pm 1.9$ & 4344 & 54.6 & 49.8 & $51.5 \pm 1.3$ \\
\hline$\left(\mathrm{kg} \mathrm{m}^{-2}\right)$ & H-B & 17,422 & 58.2 & 1.71 & $52.9 \pm 3.8$ & 4294 & 58.2 & 1.71 & $51.0 \pm 6.6$ & 4344 & 55.0 & 52.3 & $53.4 \pm 0.5$ \\
\hline Hen age & H-A & 17,520 & 858 & 110 & $469 \pm 210$ & 4416 & 619 & 161 & $396 \pm 215$ & 4344 & 800 & 334 & $571 \pm 185$ \\
\hline (d) & H-B & 17,520 & 830 & 117 & $481 \pm 209$ & 4392 & 804 & 117 & $378 \pm 193$ & 4344 & 737 & 281 & $509 \pm 185$ \\
\hline Manure & $\mathrm{H}-\mathrm{A}$ & 17,544 & 1707 & 95 & $815 \pm 426$ & 4416 & 1707 & 95 & $1075 \pm 591$ & 4344 & 959 & 516 & $730 \pm 111$ \\
\hline weight (Mg) & H-B & 17,544 & 2720 & 100 & $1411 \pm 732$ & 4416 & 1689 & 100 & $1165 \pm 491$ & 4344 & 2381 & 594 & $1491 \pm 723$ \\
\hline
\end{tabular}

*Summer included days from June 1 to August 31; winter included days from December 1 to the next February 28 or 29. 
Ventilation rates in $\mathrm{H}-\mathrm{A}$ ranged from 12.7 to $723.9 \mathrm{~m}^{3} \mathrm{~s}^{-1}$ with an average of $183.2 \pm 195.3 \mathrm{~m}^{3} \mathrm{~s}^{-1}$ (mean \pm standard deviation), which were slightly lower than that in H-B (ranging from 20.0 to $731.2 \mathrm{~m}^{3} \mathrm{~s}^{-1}$ with an average of $200.0 \pm 209.1 \mathrm{~m}^{3}$ $\left.\mathrm{s}^{-1}\right)$. In spite of the higher ventilation rate in $\mathrm{H}-\mathrm{B}$, the two-year average $\mathrm{NH}_{3}$ concentration was still higher in $\mathrm{H}-\mathrm{B}(52.0 \pm 41.8$ ppm) than in $\mathrm{H}-\mathrm{A}(48.9 \pm 40.6 \mathrm{ppm})$. This was probably because that the amount of manure in H-B was twice as much as that in $\mathrm{H}-\mathrm{A}$, resulted from fewer manure removals from H-B. Moreover, the inlet on the attic of $\mathrm{H}-\mathrm{B}$ faced to the north, open to the space between the two houses where the background concentrations were elevated by the exhaust of both houses. This was confirmed by the higher measured inlet $\mathrm{NH}_{3}$ concentration for $\mathrm{H}-\mathrm{B}$ (2.2 ppm) than H-A (1.7 ppm). The mean of outdoor T and RH were $12.3 \pm 11.8{ }^{\circ} \mathrm{C}$ and $68.5 \pm 18.2 \%$, respectively, during the study.

New flocks were introduced into H-A during April 2009 and H-B during June 2007. There was one empty-house day when the old flock was all moved out and the new flock was not yet moved in for each house during the two-year monitoring. The empty-house days were excluded from the dataset for modeling. Hens were molted according to industry standards. The molting days were included in the dataset. The bird live mass density remained quite constant during the two years of study and averaged $52.4 \pm 3.6 \mathrm{~kg} \mathrm{~m}^{-2}$ and $52.9 \pm 3.8 \mathrm{~kg} \mathrm{~m}^{-2}$ in $\mathrm{H}-\mathrm{A}$ and $\mathrm{H}-\mathrm{B}$, respectively.

The approximate weight of manure in the pits averaged $815 \mathrm{Mg}$ in $\mathrm{H}-\mathrm{A}$ and $1411 \mathrm{Mg}$ in H-B. The considerate difference in manure weight was because manure was loaded out twice from July to August in 2007 and 2008 from H-A manure pit while removal was only done once from July to August in 2007 from $\mathrm{H}-\mathrm{B}$.

\subsection{Model Development}

A DLNM to predict the lagged effects of ventilation rate, outdoor T, and outdoor $\mathrm{RH}$ on indoor $\mathrm{NH}_{3}$ concentrations was developed based on the analysis of various primary influencing factors and paths.

\subsubsection{Analysis of Influencing Factors and Paths on Ammonia Concentrations}

Factors and pathways affecting $\mathrm{NH}_{3}$ concentrations in the houses were analyzed based on the observations at the monitoring site and the current knowledge published in the literature to develop a diagram, which was to explain the inputs and outputs of the housing system and the interactions of different factors on $\mathrm{NH}_{3}$ concentrations. Delayed effects between different variables with different time durations, e.g., the dynamic influences of increasing ventilation rate on decreasing the $\mathrm{NH}_{3}$ concentration, were estimated with days, hours, minutes, or seconds. These results of the analysis were used to assist selection of variables and time lags during the modeling.

\subsubsection{The Distributed Lag Non-linear Model}

The DLNM was chosen as a modeling tool in this study. Ventilation rate, outdoor $\mathrm{T}$ and outdoor $\mathrm{RH}$ were discussed as major environmental influencing factors, as reported by previous studies (Weaver and Meijerhof, 1991; Wheeler et al., 2006; Lin et al., 2012), and their lagged effects were investigated by DLNM. The reason for using DLNM was that it can simultaneously represent the delayed and non-linear dependencies between $\mathrm{NH}_{3}$ concentrations and the variables of interest. A detailed description of the mathematics of this modeling method is available (Gasparrini, 2011). In addition to the three variables of interest included in the three cross-basis (ventilation rate, outdoor $\mathrm{T}$, and outdoor $\mathrm{RH}$ ), live mass density (LMD), hen age (HA), manure weight (MW), house lighting (L), and molting (M) were also incorporated into the model via non-linear link functions because these variables have been demonstrated to be closely related to $\mathrm{NH}_{3}$ concentrations in layer houses (Ni et al., 2010; Morgan et al., 2014).

A DLNM combined with a Gaussian regression model was developed for the two layer houses and represented in Equation (1):

$$
\begin{aligned}
C\left(N H_{3}\right) & =\sum_{i=1}^{3} s_{i}\left(x_{i}, \boldsymbol{\beta}_{i}\right)+n s\left(\mathbf{L M D}, d f_{1}\right)+n s\left(\mathbf{H A}, d f_{2}\right) \\
& +n s\left(\mathbf{M W}, d f_{3}\right)+n s\left(\mathbf{t}, d f_{4}\right)+A F(\mathbf{L})+A F(\mathbf{M})
\end{aligned}
$$

where: $\mathrm{C}\left(\mathrm{NH}_{3}\right)$ is expected hourly mean $\mathrm{NH}_{3}$ concentrations, ppm; $s_{i}($.$) is a matrix; x_{i}$ is for ventilation rate $\left(\mathrm{m}^{3} \mathrm{~s}^{-1}\right)$, outdoor $\mathrm{T}\left({ }^{\circ} \mathrm{C}\right)$, and outdoor $\mathrm{RH}(\%) ; \mathbf{\beta}_{i}$ is a parameter vector; $n s($.$) is a$ natural cubic spline function; LMD is hen live mass density, $\mathrm{kg}$ $\mathrm{m}^{-2} ; \mathbf{H A}$ is hen age, day; $\mathbf{M W}$ is manure weight, $\mathrm{Mg} ; d f_{l}-d f_{4}$ are degree of freedom; $\mathbf{t}$ is time, $\mathrm{h} ; A F($.$) is as factor; \mathbf{L}$ and $\mathbf{M}$ are categorical light factor and molting factor, respectively, 1 or 0 .

The matrix $\mathrm{s}_{\mathrm{i}}($.$) was generated by DLNM to analyze the$ non-linear and the distributed lag effects of the influencing factors (ventilation rate, outdoor $\mathrm{T}$, and $\mathrm{RH}$ ) over the current time (lag 0) to 24 hours (lag 24) thereafter, called cross-basis. The means of the influencing factors were used as reference values to center each cross-basis and calculate relative variations of $\mathrm{NH}_{3}$ concentrations. The natural cubic spline function ns(.) was used according to the recommendations in the literature (Gasparrini, 2011) and good fittings of this dataset and subsets. All the spline knots were equally spaced to allow enough flexibility of fitting. The time $\mathbf{t}$ is a term to control hourly time confounders. It was used in analyzing the two-year hourly data in $\mathrm{H}-\mathrm{A}$ and $\mathrm{H}-\mathrm{B}$, but removed from the model in seasonal lagged effects analysis because the subsets covered shorter periods. The categorical light factor $\mathbf{L}$ was chosen as 1 when the house lights were on and 0 when they were off. The categorical light factor $\mathbf{M}$ was applied to the data set overlapped with the molting period, chosen as 1 when the birds were on molting.

All statistical tests were performed two-sided and based on a $P$ value of 0.05 considered significant. Model selection and parameter optimization, including the selection of the appropriate type of connecting function for each dimension and relevant degree of freedom, were based on the modified Akaike Information Criteria (AIC). 
Table 2. Degree of Freedoms $(d f)$ Selected in the Models for Different Data Sets

\begin{tabular}{lllllll}
\hline & 2 -yr H-A & 2-yr H-B & Summer H-A & Summer H-B & Winter H-A & Winter H-B \\
\hline Ventilation rate* & 7 & 7 & 6 & 7 & 6 & 4 \\
Outdoor T* & 6 & 4 & 5 & 6 & 5 & 3 \\
Outdoor RH* & 5 & 3 & 5 & 4 & 5 & 3 \\
Live mass density (LMD) & 6 & 5 & 5 & 5 & 6 & 4 \\
Hen age (HA) & 6 & 4 & 6 & 6 & 4 & 5 \\
Manure weight (MW) & 7 & 6 & 8 & 6 & 9 & 6 \\
Time (t) & 5 & 5 & - & - & - & - \\
\hline
\end{tabular}

*Ventilation rate, outdoor T and outdoor RH were in respective cross-basis, where the variances were controlled in both predictor and lag spaces. In the predictor space, the natural cubic spline was applied, along with the $d f$ in the table; while in the lag space, 3 internal knots were placed at equally-spaced log-values.

Additional sensitivity analyses were completed by extending time lags of interest and testing alternative degrees of freedom $(d f=6-10)$ for the variables. The model was finalized when the AIC and predicted results were stabilized. In order to make sure whether the observed effects were related with the specific variable of interest, the estimation of the model was compared with that of the model without this specific variable. The finalized degree of freedom based on the model selection procedures is listed in Table 2. The selected DLNM was used to predict the effects in both predictors and lag spaces with confidence intervals at the specific significance level.

\section{Results and Discussion}

\subsection{Factors and Pathways Affecting Ammonia Concentra- tions}

The layer houses were complex dynamic environment systems that interacted externally and internally with a variety of physical, biological, and managerial factors. These interactions were not merely affected by the influencing factors at the current time, but for several subsequent hours. Ammonia concen- tration in the layer houses depended on the indoor and outdoor environmental conditions, house management practices, and livestock and manure conditions (Figure 1).

\subsubsection{Outdoor and Indoor Environments}

Outdoor environmental or meteorological factors, such as outdoor T and outdoor RH, influenced indoor environment and played an indirect role on indoor $\mathrm{NH}_{3}$ concentrations. Outdoor $\mathrm{T}$ was largely depended on the solar radiation, and therefore, was highly associated with the day of the year. It also determined the magnitude of deviation from the set point temperature, affecting the ventilation, indoor temperature, RH and moisture content in manure as a result. Although indoor temperature remained quite constant (Morgan et al., 2014), higher outside temperature was still followed by higher inside temperatures, resulting in enhanced biological and physical activities related to elevated $\mathrm{NH}_{3}$ generation and release (Groot Koerkamp et al., 1998; Pratt et al., 2002; Kaasik and Maasikmets, 2013). A slight increase of temperature of $1-2^{\circ} \mathrm{C}$ could have significant effects on $\mathrm{NH}_{3}$ concentration in the intensive housing (Elliott and Collins, 1982). The probable delayed effects

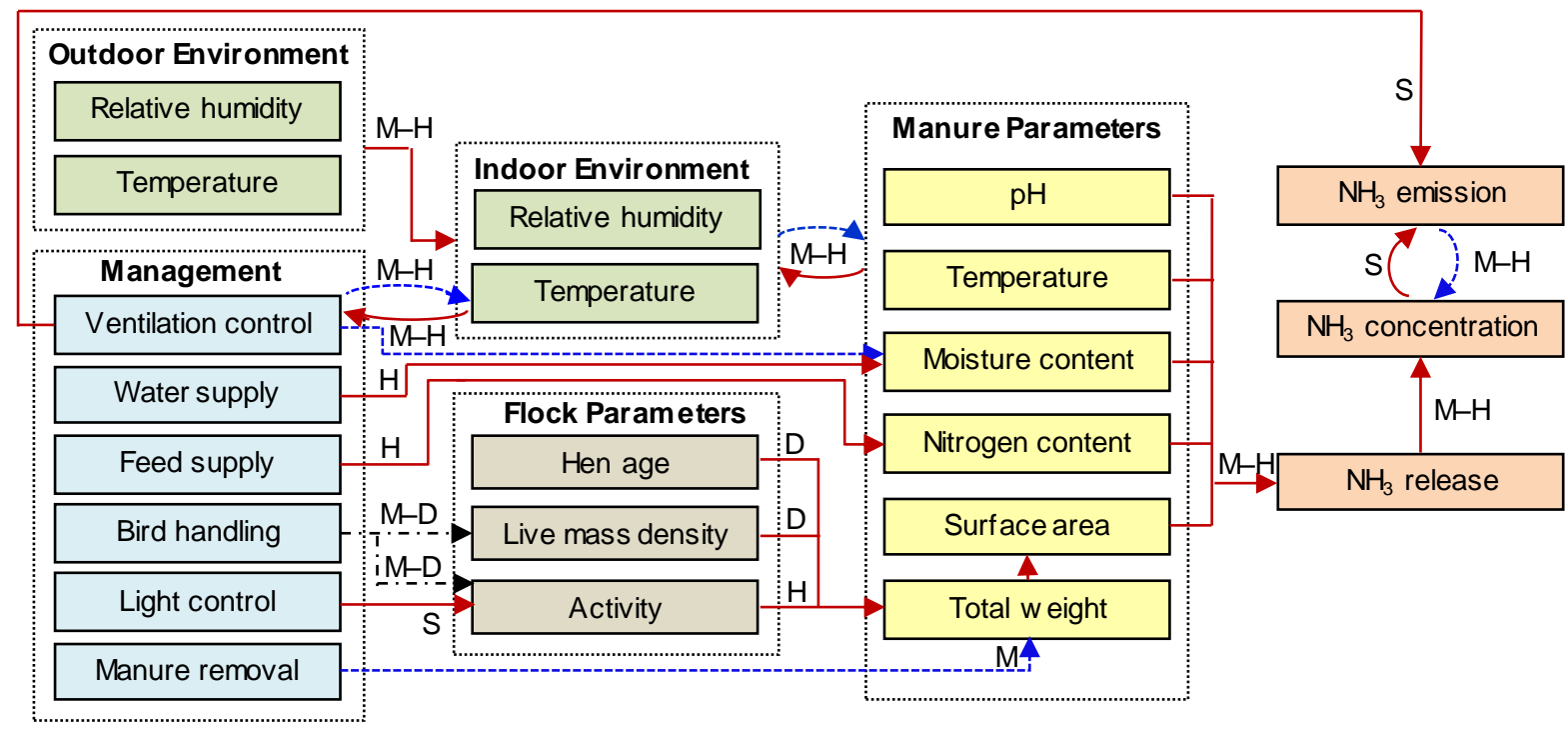

Figure 1. Factors and pathways affecting $\mathrm{NH}_{3}$ concentrations in the high-rise layer house systems and probable time delays (D = days, $\mathrm{H}=$ hours, $\mathrm{M}=$ minutes, $\mathrm{S}=$ seconds). Arrows in solid, dot, and dot-dash lines indicate positive, negative, and complex interactions, respectively. 
of outdoor environment on indoor temperature and $\mathrm{RH}$ were from minutes to several hours depending on how house ventilation was controlled at the time.

Higher indoor RH was experimentally demonstrated to increase $\mathrm{NH}_{3}$ level in the poultry house, because it led to less water evaporation and caking over manure surface. As a result, higher moisture content remained in the manure surface and increased $\mathrm{NH}_{3}$ volatilization (Weaver and Meijerhof, 1991). On the other hand, lower indoor RH was suggested to be related to higher total particulate matter in the air due to lowered equilibrium moisture content. Since up to $23 \%$ of airborne $\mathrm{NH}_{3}$ in the livestock houses could be absorbed by the particulate matter, especially PM2.5 (Reynolds et al., 1998), airborne suspending $\mathrm{NH}_{3}$ increased rather than being absorbed as the $\mathrm{RH}$ went up (Takai et al., 1998; Takai et al., 2002; Vučemilo et al., 2008).

\subsubsection{Managerial Parameters}

Management strategies, such as ventilation control, bird handling, manure removal, and the supply of feed, water, and light, have comprehensive effects on birds, manure, and indoor condition. Ventilation brought in large quantities of outside air and accelerated the air exchange in the barn, resulted in enhanced velocity of airflow above manure surface and promoted mass transfer of $\mathrm{NH}_{3}$ from manure surface to the air. It played a role not only in indoor temperature, $\mathrm{RH}$, and moisture evaporation from manure, but also in particle formation / distribution to a large extent (Groot Koerkamp et al., 1998; Calvet et al., 2010). In a specific high-rise layer house, ventilation rate, along with outdoor T, were considered to be the two key factors leading to concentration variations during the day (Groot Koerkamp, 1994; Ni et al., 2000; Bjerg et al., 2013).

The relationship between birds' diet and excreted nitrogen contents has been widely studied. While Summers et al. (1993) and Roberts et al. (2007) successfully reduced the amount of excreted nitrogen by diet manipulations, Murakami et al. (2011) claimed no significant effects of crude protein percentage in diet on the amount of total $\mathrm{N}$ and uric acid-N in fresh litter of layer hens. Manure removal strategy determined both the amount and the surface area of manure remaining in the pit. In this study, the frequency of manure removal was higher in H-A than that in H-B. Light supply kept birds staying active of $16 \mathrm{~h}$ during the day when they were excreting more frequently (Wang Li et al., 2013). Bird handling, including bird replacement and molting, influenced the amount of manure in the pit. Bird replacement determine the average bird age in each house. Molting was a strategy to stimulate hen productivity, accompanied by reduced indoor temperature, decreased food and water supply, and shortened lighting period. Birds became less active and generated less excretion during molt.

\subsubsection{Flock Parameters}

Hen activity was highly related to manure excretion (Wang -Li et al., 2013). Hens of different age were fed respective feed formula, resulting in different nitrogen contents in the manure (Wang-Li et al., 2013). Hen age and breed were also reported to influence the weight and percentage of dry matter in the manure (Mendes et al., 2012). Live mass density is an indicator of the number of live birds excreting in the house and is related to the cage temperature due to their body heat. Hen age, activety, and live mass density highly affected the quantities and properties of manure in the houses and were therefore associated with the release of $\mathrm{NH}_{3}$.

\subsubsection{Manure Parameters}

The release of $\mathrm{NH}_{3}$ from manure was affected by a variety of manure properties, including $\mathrm{pH}$, temperature, nitrogen content, moisture content, manure age, and surface area. The increase of moisture content in the poultry manure enhanced the release of $\mathrm{NH}_{3}$ by accelerating the microbial-mediated decomposition of organic nitrogen (Miles et al., 2004). However, it could suppress the $\mathrm{NH}_{3}$ release when the moisture content continued to increase after exceeding an upper limit (Miles et al., 2011). Pit temperature and manure $\mathrm{pH}$ played a role in the proportion of ionized ammonium $\left(\mathrm{NH}^{4+}\right)$ and un-ionized ammonia $\left(\mathrm{NH}_{3}\right)$ in the manure (Groot Koerkamp, 1994), which were both primary forms of $\mathrm{NH}_{3}$ existing in the manure. Nahm et al. (2003 ) reported a ranked order of the factors influencing $\mathrm{NH}_{3}$ generation: manure $\mathrm{pH}>$ pit temperature $>$ moisture content.

\subsubsection{Ammonia Release, Emission, and Concentration}

Indoor $\mathrm{NH}_{3}$ concentration in the high-rise layer houses was a dynamic balance of the amount released from the manure piles in the pit and the manure on various surfaces on the second floor, and the amount emitted to the outdoor environment via house ventilation. There were no general agreements on the estimated time lags between manure excretion and $\mathrm{NH}_{3}$ release in the literature. Some authors reported that it required 2 to 2.5 min for $\mathrm{NH}_{3}$ to release from a concrete floor of a cattle farm where urea was sprinkled onto, and there was a delay of several hours between urea deposition and the maximum $\mathrm{NH}_{3}$ release (Elzing and Monteny, 1997). Li (2006) suggested a time delay of several hours to a few days for $\mathrm{NH}_{3}$ to be generated from the microbial decomposition of urea and uric acid in fresh layer manure. Otherwise, Pereira et al. (2011) observed immediate $\mathrm{NH}_{3}$ release after cattle excreta deposited on the floor, but the peak flux varied at different time within the first $24 \mathrm{~h}$, depending on the environmental temperature. Among these studies, the differences between the estimations of the time lags were largely dependent on the properties of manure and the microclimate around the manure, including the air speed over the manure surface, temperature, and RH.

\subsection{Dynamic $\mathrm{NH}_{3}$ Concentrations in the Layer Houses}

Lagged effects of ventilation rate, outdoor $\mathrm{T}$, and outdoor $\mathrm{RH}$ on $\mathrm{NH}_{3}$ concentrations were obtained based on the predicttion of the DLNM [Equation (2)], shown in 3-D surface figures (Figures 2 and 3). In addition to the previously reported seasonal variations of $\mathrm{NH}_{3}$ concentrations in high-rise layer houses (Liang et al., 2005; Lin et al., 2012; Ni et al., 2012; Wang-Li et al., 2013), this study demonstrated substantial seasonal differrences between the dynamic relationships of $\mathrm{NH}_{3}$ concentration and its influencing factors. 

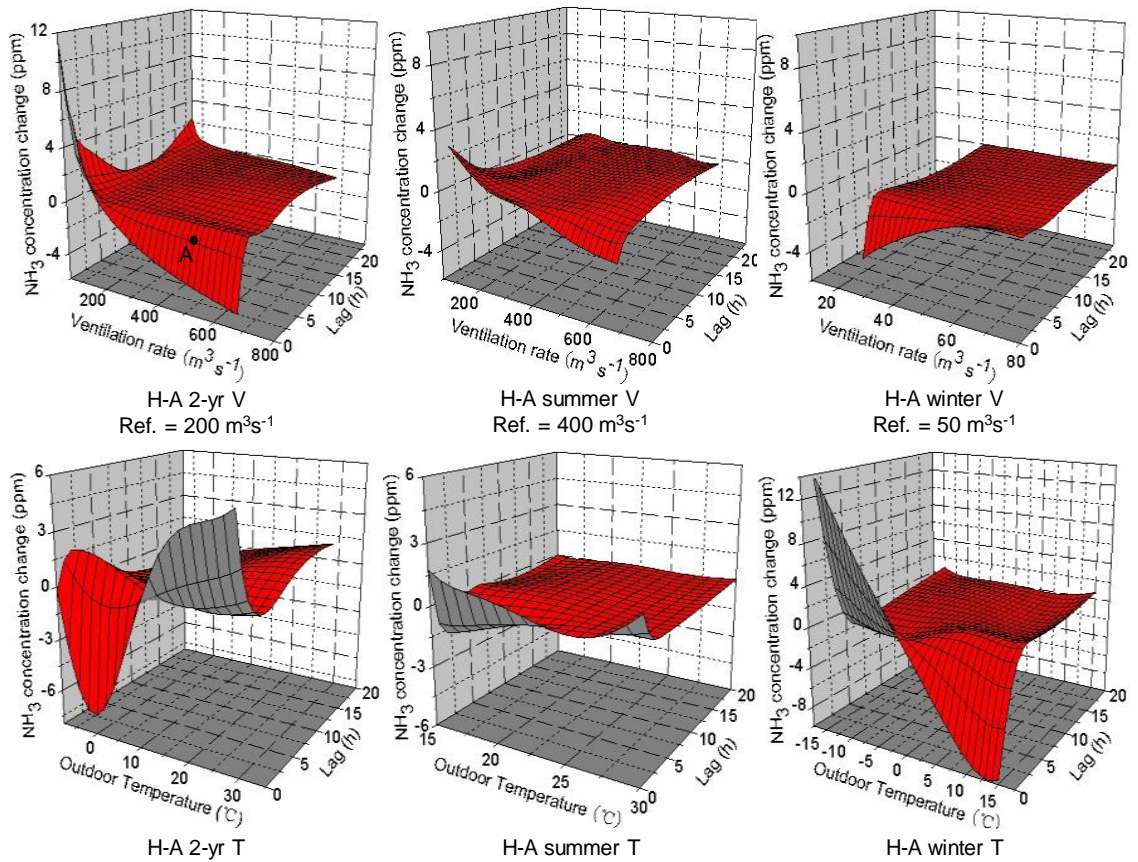

Ref. $=10^{\circ} \mathrm{C}$
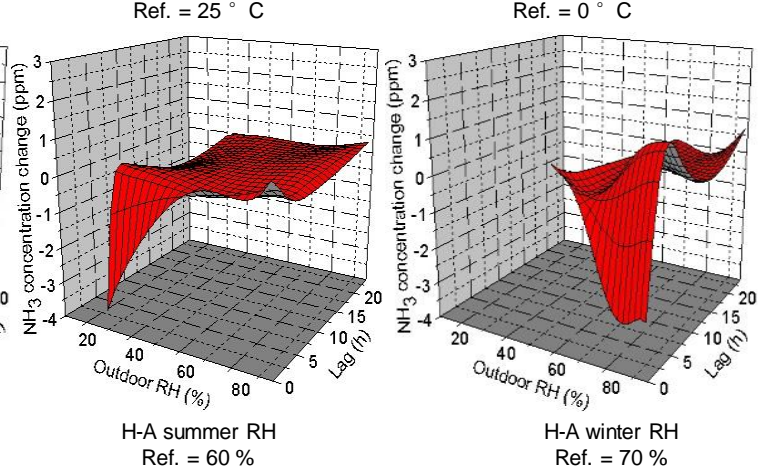
H-A summer RH
Ref. $=60 \%$

Ref. $=70 \%$

Figure 2. Lagged effects of ventilation $(\mathrm{V})$, outdoor $\mathrm{T}(\mathrm{T})$, and outdoor RH (RH) with three different reference values on $\mathrm{NH}_{3}$ concentrations in $\mathrm{H}-\mathrm{A}$ using the twoyear, summer, and winter data. The $\mathrm{x}$-axis is the scale of a specific influencing factor, such as ventilation rate $\left(\mathrm{m}^{3} \mathrm{~s}^{-1}\right)$, outdoor $\mathrm{T}\left({ }^{\circ} \mathrm{C}\right)$ and outdoor $\mathrm{RH}(\%)$; y-axis is the lag in time (h); $\mathrm{z}$-axis is the change of $\mathrm{NH}_{3}$ concentration compared with the reference at a specific time.
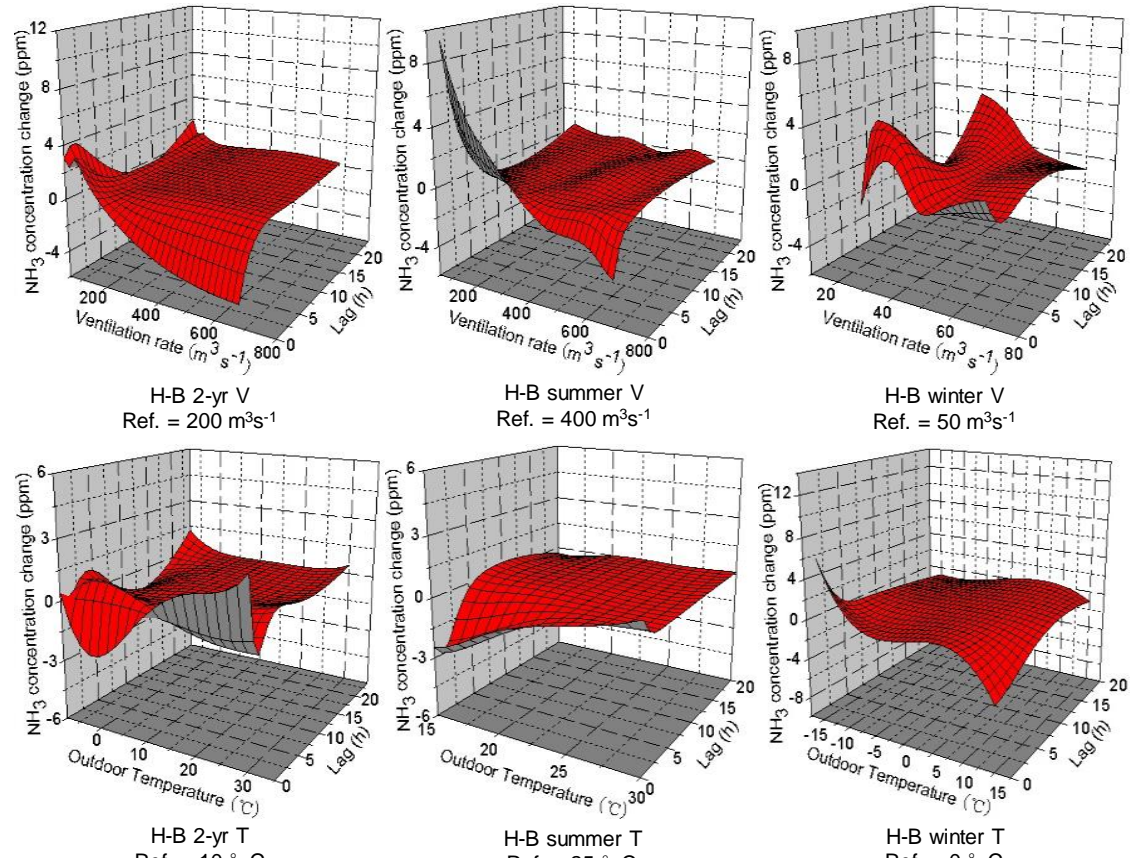

H-B $2-y \mathrm{y}^{\mathrm{T}}$
Ref. $=10^{\circ} \mathrm{C}$

H-B summer T
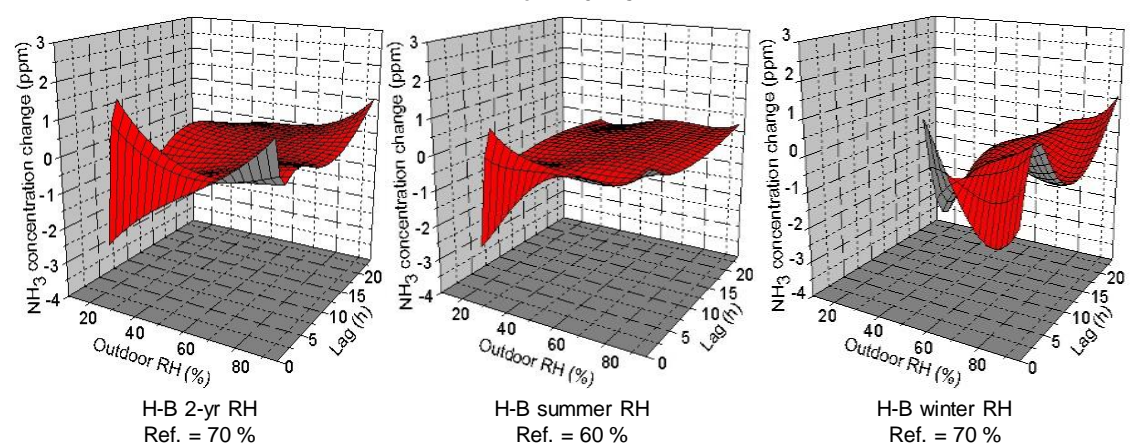

Figure 3. Lagged effects of ventilation $(\mathrm{V})$, outdoor $\mathrm{T}(\mathrm{T})$, and outdoor RH $(\mathrm{RH})$ with three different reference values on NH3 concentrations in $\mathrm{H}-\mathrm{B}$ using the twoyear, summer, and winter data. The $\mathrm{x}$-axis is the scale of a specific influencing factor, such as ventilation rate $(\mathrm{m} 3 \mathrm{~s}-1)$, outdoor $\mathrm{T}\left({ }^{\circ} \mathrm{C}\right)$ and outdoor $\mathrm{RH}(\%)$; yaxis is the lag in time (h); $\mathrm{z}$-axis is the change of $\mathrm{NH} 3$ concentration compared with the reference at a specific time. 
3.2.1. Lagged Effects of Ventilation Rate on $\mathrm{NH}_{3}$ Concentrations

Ventilation rates were inversely related to $\mathrm{NH}_{3}$ concentrations as shown in Figure $2 \mathrm{H}-\mathrm{A} 2-\mathrm{yr} \mathrm{V}$ and Figure $3 \mathrm{H}-\mathrm{B}$ 2-yr $\mathrm{V}$. For example, the dot A in $\mathrm{H}-\mathrm{A} 2-\mathrm{yr} \mathrm{V}$ means that $\mathrm{NH}_{3}$ concentrations decreased by about $2 \mathrm{ppm} 1 \mathrm{~h}$ after the ventilation rate had increased from 200 to $400 \mathrm{~m}^{3} \mathrm{~s}^{-1}$. Increased ventilation rates were associated with decreased $\mathrm{NH}_{3}$ concentrations and vice versa. These effects lasted for less than a few hours. Although variations in ventilation rates led to greater fluctuations of $\mathrm{NH}_{3}$ concentrations in $\mathrm{H}-\mathrm{A}$ than in $\mathrm{H}-\mathrm{B}$ for the two-year data, the time lag patterns were quite consistent between the two houses when the reference $\mathrm{NH}_{3}$ concentrations for both houses were set at a ventilation rate of $200 \mathrm{~m}^{3} \mathrm{~s}^{-1}$, which was the two-year mean.

However, the delayed effects caused by each of the influencing factors cannot be determined by those 3-D figures alone. Instead, lag-specific plots with $95 \%$ confidence intervals (CIs) at a specific variable level were expected to help identify real-time lag patterns (Figures 4 to 6). These selected levels were the 10th and 90th percentile of the variable of interest. Only the points with CIs covering all non-zero values can be considered as statistically significant effects.
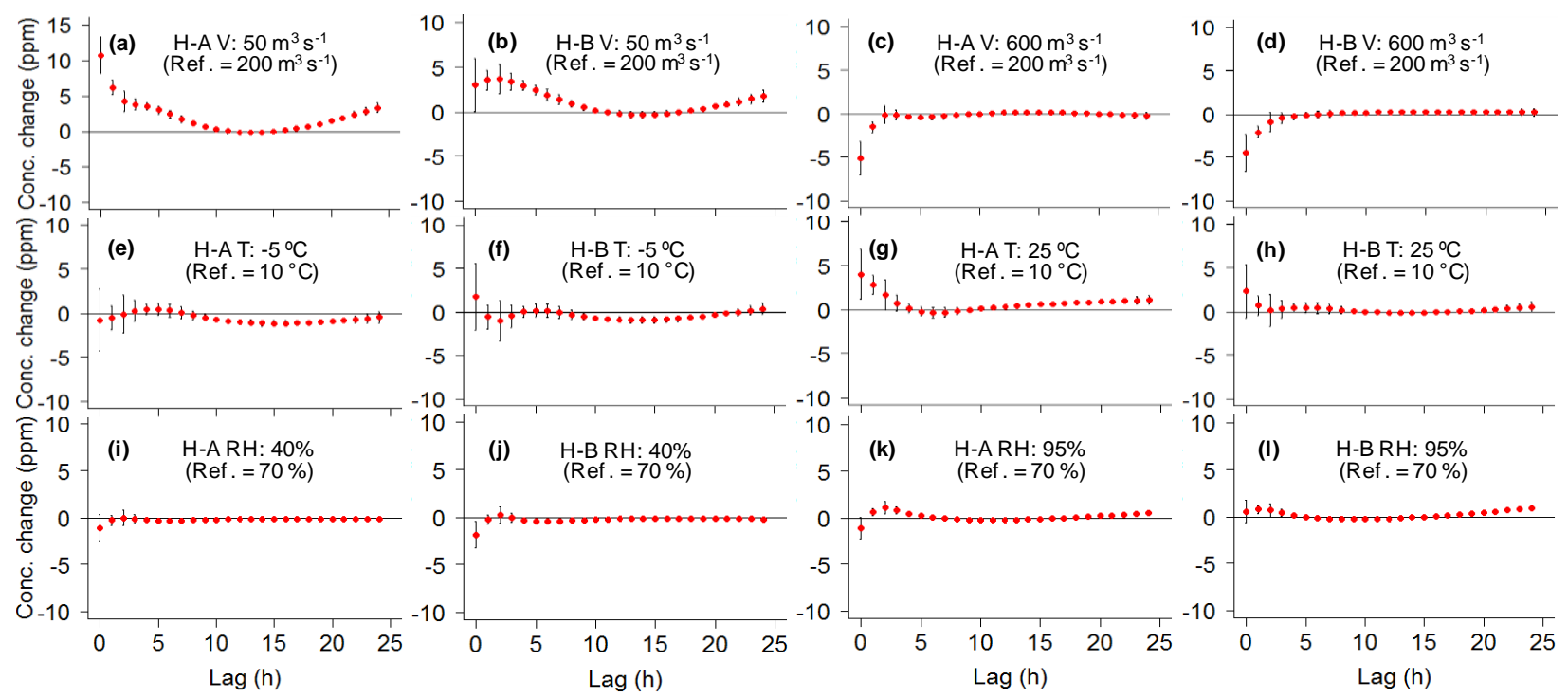

Figure 4. Lagged effects of ventilation (V), outdoor T (T), and outdoor RH (RH) on NH3 concentrations in H-A and H-B using the two-year data. Error bars indicate the $95 \%$ confidence interval.
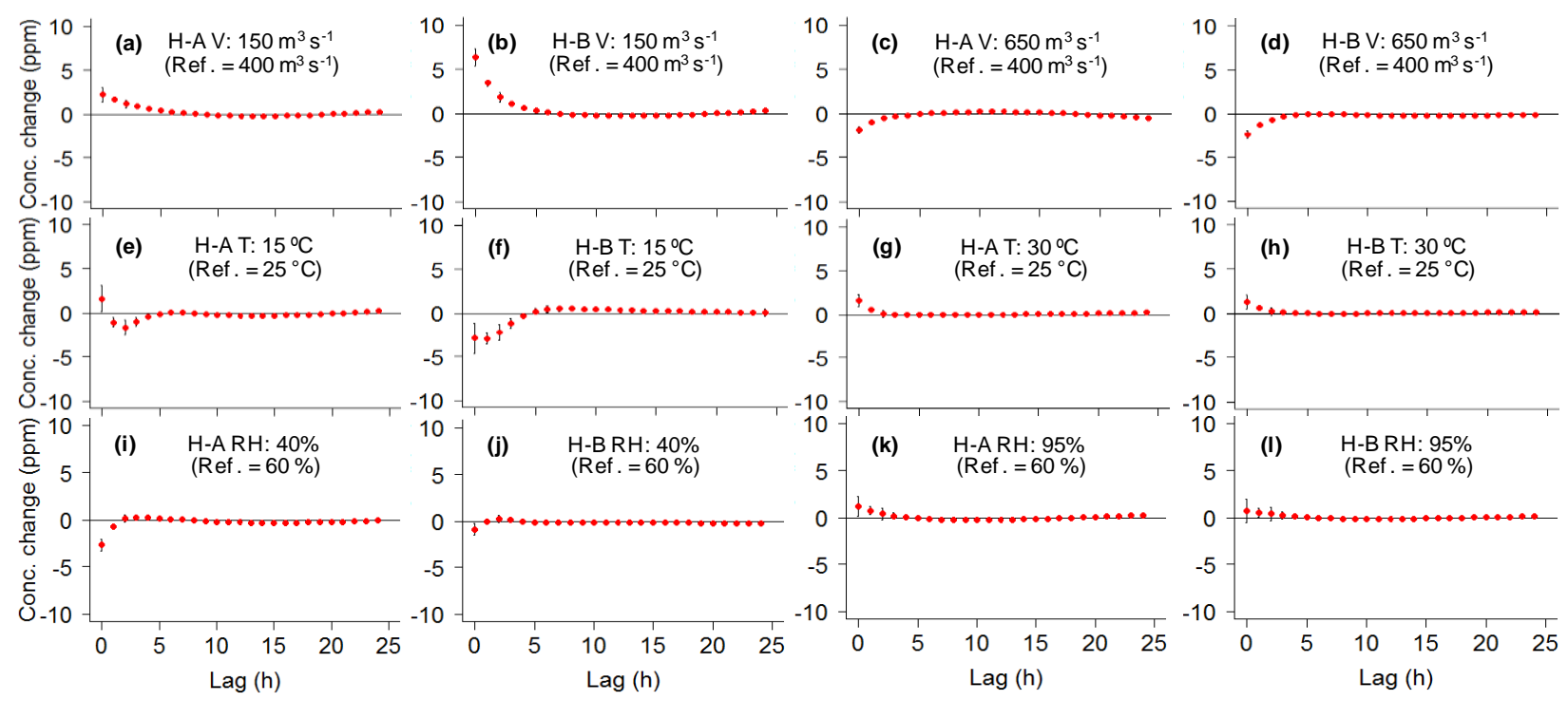

Figure 5. Lagged effects of ventilation (V), outdoor $\mathrm{T}(\mathrm{T})$, and outdoor RH (RH) on NH3 concentrations in H-A and H-B using the summer data. Error bars indicate the $95 \%$ confidence interval. 

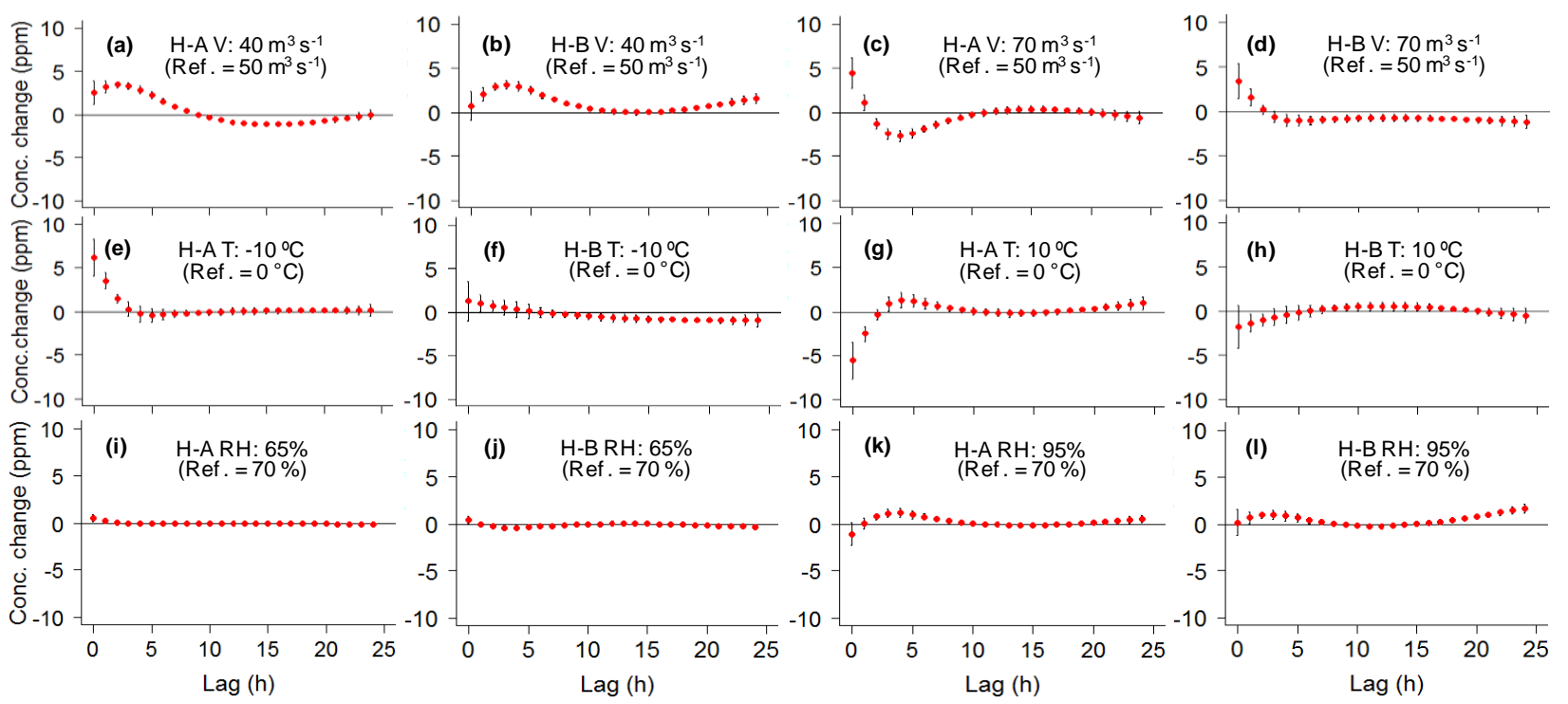

Figure 6. Lagged effects of ventilation (V), outdoor T (T), and outdoor RH (RH) on NH3 concentrations in H-A and H-B using the winter data. Error bars indicate the $95 \%$ confidence interval.

In the two years of study, the lag-specific plots at ventilation rate of $50 \mathrm{~m}^{3} \mathrm{~s}^{-1}$ and $600 \mathrm{~m}^{3} \mathrm{~s}^{-1}$ both showed the expected lagged effects at $95 \%$ CIs (Figure $4 \mathrm{a}-\mathrm{d}$ ). When the ventilation rate decreased from 200 to $50 \mathrm{~m}^{3} \mathrm{~s}^{-1}$, the indoor $\mathrm{NH}_{3}$ concentrations increased by about $12 \mathrm{ppm}$ in $\mathrm{H}-\mathrm{A}$ and $3 \mathrm{ppm}$ in $\mathrm{H}-\mathrm{B}$ at the current time (lag 0 ). The elevated $\mathrm{NH}_{3}$ concentration persisted for up to $9 \mathrm{~h}$ in both houses under this particular situation (Figure $4 \mathrm{a}-\mathrm{b}$ ). When the ventilation rate changed from 200 to $600 \mathrm{~m}^{3} \mathrm{~s}^{-1}, \mathrm{NH}_{3}$ concentrations decreased by about $5 \mathrm{pm}$ from the reference level without observable time delay (lag time $<1$ h) in both houses. The $\mathrm{NH}_{3}$ concentrations remained at lowered level for $2 \mathrm{~h}$ (Figure $4 \mathrm{c}-\mathrm{d}$ ).

In summer, the ventilation systems were in full operation to keep moderate indoor temperatures in hot weather. The average ventilation rates were $397.8 \pm 212.3$ and $421.6 \pm 214.5 \mathrm{~m}^{3}$ $\mathrm{s}^{-1}$ in $\mathrm{H}-\mathrm{A}$ and $\mathrm{H}-\mathrm{B}$, respectively (Table 1 ). Although summer ventilation caused larger variations in $\mathrm{NH}_{3}$ concentrations in $\mathrm{H}-$ $\mathrm{B}$ than in $\mathrm{H}-\mathrm{A}$, a negative relationship between ventilation rates and $\mathrm{NH}_{3}$ concentrations remained in both houses (Figure $2 \mathrm{H}$ A summer $\mathrm{V}$ and Figure $3 \mathrm{H}-\mathrm{B}$ summer $\mathrm{V}$ ) when the reference $\mathrm{NH}_{3}$ concentration was set at the ventilation rate of $400 \mathrm{~m}^{3} \mathrm{~s}^{-1}$. When the ventilation rate declined from 400 to $150 \mathrm{~m}^{3} \mathrm{~s}^{-1}$, significant increases in $\mathrm{NH}_{3}$ concentrations were observed in both houses at the current time, and the elevated concentration lasted for about 5 - $6 \mathrm{~h}$ (Figure $5 \mathrm{a}-\mathrm{b}$ ). However, when the ventilation rate increased from 400 to $650 \mathrm{~m}^{3} \mathrm{~s}^{-1}$, the indoor $\mathrm{NH}_{3}$ concentrations reduced by only $2 \mathrm{ppm}$ in both houses without observable time delay (lag time $<1 \mathrm{~h}$ ). These effects lasted for about 2 - $3 \mathrm{~h}$ (Figure $5 \mathrm{c}-\mathrm{d}$ ).

In winter the mean ventilation rates were $49.0 \pm 13.1$ and $52.2 \pm 18.2 \mathrm{~m}^{3} \mathrm{~s}^{-1}$ in $\mathrm{H}-\mathrm{A}$ and $\mathrm{H}-\mathrm{B}$, respectively, ranging from 20.0 to $186.0 \mathrm{~m}^{3} \mathrm{~s}^{-1}$ in both houses (Table 1). The patterns of lagged effects were inconsistent between $\mathrm{H}-\mathrm{A}$ and $\mathrm{H}-\mathrm{B}$ (Figure $2 \mathrm{H}-\mathrm{A}$ winter $\mathrm{V}$ and Figure $3 \mathrm{H}-\mathrm{B}$ winter V). Larger fluctuations of $\mathrm{NH}_{3}$ concentrations caused by the changes of venti- lation in $\mathrm{H}-\mathrm{B}$ than that in $\mathrm{H}-\mathrm{A}$, when the reference $\mathrm{NH}_{3}$ concentration was set at the ventilation rate of $50 \mathrm{~m}^{3} \mathrm{~s}^{-1}$. However, those fluctuations were within $\pm 5 \mathrm{ppm}$ in both houses. Decreases of ventilation rates from $50 \mathrm{~m}^{3} \mathrm{~s}^{-1}$ to $40 \mathrm{~m}^{3} \mathrm{~s}^{-1}$ still led to augmenting $\mathrm{NH}_{3}$ concentrations in both houses, with $1 \mathrm{~h}$ lag in $\mathrm{H}-\mathrm{B}$ and no observable lag time in H-A (Figure $6 \mathrm{a}-\mathrm{b}$ ). However, the effects of increased ventilation rates from $50 \mathrm{~m}^{3}$ $\mathrm{s}^{-1}$ to $70 \mathrm{~m}^{3} \mathrm{~s}^{-1}$ were not consistent in both houses, because the CIs of lag-specific plots at a higher ventilation rate $\left(70 \mathrm{~m}^{3} \mathrm{~s}^{-1}\right)$ were close to zeros over almost all lags in H-B (Figure $6 \mathrm{c}-\mathrm{d}$ ). Unlike in the summer, the ventilation was maintained at minimum levels (from 34.3 to $83.4 \mathrm{~m}^{3} \mathrm{~s}^{-1}$ for $90 \%$ of the time) to maintain indoor temperatures. Even at the high end of winter ventilation rate of about $70 \mathrm{~m}^{3} \mathrm{~s}^{-1}$, the lagged effect of ventilation on $\mathrm{NH}_{3}$ concentrations still could not be identified in this study. This phenolmenon could be explained by the study of Sevi et al. (2003), who concluded that very low ventilation rate resulted in inefficient removal of $\mathrm{NH}_{3}$ from animal barns.

\subsubsection{Lagged Effect of Outdoor Temperature on $\mathrm{NH}_{3}$ Concen- trations}

The lagged effects of outdoor $\mathrm{T}$ in the two houses reached a consistent level based on the two-year data when the reference $\mathrm{NH}_{3}$ concentration was set at $10{ }^{\circ} \mathrm{C}$ (Figure $2 \mathrm{H}-\mathrm{A} 2-\mathrm{yr} \mathrm{T}$ and Figure $3 \mathrm{H}-\mathrm{B}$ 2-yr T). Outdoor T influenced $\mathrm{NH}_{3}$ release by altering the temperature in the pit when a large quantity of air flow was mechanically introduced into the buildings (Groot Koerkamp et al., 1998). In both houses, the effects of low temperature $\left(-5^{\circ} \mathrm{C}\right)$ were not observed until $9 \mathrm{~h}$ later when decreeses in $\mathrm{NH}_{3}$ concentrations by 1 - 2 ppm were observed (Figure $4 \mathrm{e}-\mathrm{f}$ ). This process persisted for more than another $9 \mathrm{~h}$, and could be explained by both the inhibited microbial activity in the manure and repressed $\mathrm{NH}_{3}$ release. However, high temperature $\left(25^{\circ} \mathrm{C}\right)$ enhanced $\mathrm{NH}_{3}$ concentrations by about $5 \mathrm{ppm}$ at the current time in $\mathrm{H}-\mathrm{A}$, but had no significant effects in $\mathrm{H}-\mathrm{B}$ 
(Figure $4 \mathrm{~g}-\mathrm{h}$ ). Therefore, it was difficult to claim that there were effects of high outdoor $\mathrm{T}$ on indoor $\mathrm{NH}_{3}$ concentrations based on the two-year dataset.

During the summer, the delayed effects of outdoor $\mathrm{T}$ were similar with each other in both houses when the reference $\mathrm{NH}_{3}$ concentration was set at $25^{\circ} \mathrm{C}$, which was the mean in summer (Figure $2 \mathrm{H}$-A summer $\mathrm{T}$ and Figure $3 \mathrm{H}-\mathrm{B}$ summer T). In both houses, decreases in outdoor $\mathrm{T}$ by $10{ }^{\circ} \mathrm{C}$ from $25{ }^{\circ} \mathrm{C}$ reduced $\mathrm{NH}_{3}$ concentrations by about $2 \mathrm{ppm}$, in spite of an 1-h delay in $\mathrm{H}-\mathrm{A}$. These "cold effects" lasted for 4 - 5 h (Figure 5 e - f). In contrast, increases in outdoor $\mathrm{T}$ by $5{ }^{\circ} \mathrm{C}$ from $25{ }^{\circ} \mathrm{C}$ elevated $\mathrm{NH}_{3}$ concentrations by about $1-2 \mathrm{ppm}$ in both houses without observable time delay (lag time $<1 \mathrm{~h}$ ), and the higher concentration maintained for $1-2 \mathrm{~h}$ (Figure $5 \mathrm{~g}-\mathrm{h}$ ).

In winter, the time lag patterns induced by outdoor $\mathrm{T}$ changes were consistent between $\mathrm{H}-\mathrm{A}$ and $\mathrm{H}-\mathrm{B}$ when the reference $\mathrm{NH}_{3}$ concentration was selected at $0{ }^{\circ} \mathrm{C}$ (Figure $2 \mathrm{H}-\mathrm{A}$ winter $\mathrm{T}$ and Figure $3 \mathrm{H}-\mathrm{B}$ winter T). Although the variations of $\mathrm{NH}_{3}$ concentrations caused by the changes of outdoor $\mathrm{T}$ were shown during the current time and the subsequent 3-h period (lag 0 lag 4) in H-A (Figure 6 e and g), the CIs in H-B suggested insignificant effects in both cold and warm conditions (Figure $6 \mathrm{f}$ and $\mathrm{h}$ ). Low ventilation level and slow turnover of the air were underlying reasons for the limited influence of outdoor $\mathrm{T}$ on the indoor temperature, as well as $\mathrm{NH}_{3}$ release. Liang et al. (2005) suggested that the indoor temperature would not increase unless the outdoor T exceeded 8 to $10^{\circ} \mathrm{C}$ in the layer houses. As a result, conclusions on the role of temperature in winter could not be made merely based on the patterns shown in $\mathrm{H}-\mathrm{A}$.

\subsubsection{Lagged Effect of Outdoor Relative Humidity on $\mathrm{NH}_{3}$ Concentrations}

The effects of outdoor $\mathrm{RH}$ on indoor $\mathrm{NH}_{3}$ concentrations were identical for both houses based on the two-year data, when the reference was the $\mathrm{NH}_{3}$ concentration at the $\mathrm{RH}$ of $70 \%$ (Figure $2 \mathrm{H}-\mathrm{A}$ 2-yr RH and Figure $3 \mathrm{H}-\mathrm{B}$ 2-yr $\mathrm{RH}$ ). The $\mathrm{NH}_{3}$ concentrations at $95 \% \mathrm{RH}$ were $1-2 \mathrm{ppm}$ higher in both $\mathrm{H}-\mathrm{A}$ and $\mathrm{H}-\mathrm{B}$ with a time lag of $2 \mathrm{~h}$ (Figure $4 \mathrm{k}-1$ ). However, the role of low $\mathrm{RH}$ on $\mathrm{NH}_{3}$ concentrations was not fully-grounded to claim based on the analysis of the two-year dataset, because most of the $95 \%$ CIs contained zeros for both houses (Figure 4 $\mathrm{i}-\mathrm{j})$.

In summer, positive associations between outdoor RHs and indoor $\mathrm{NH}_{3}$ concentrations were shown in Figure $2 \mathrm{H}-\mathrm{A}$ summer RH and Figure $3 \mathrm{H}-\mathrm{B}$ summer $\mathrm{RH}$ when the reference was the $\mathrm{NH}_{3}$ concentration at the $\mathrm{RH}$ of $60 \%$. The $\mathrm{NH}_{3}$ concentrations at $40 \% \mathrm{RH}$ were about $2 \mathrm{ppm}$ lower than those at $60 \%$ $\mathrm{RH}$ in both houses at the current time (Figure $5 \mathrm{i}-\mathrm{j}$ ). The lower $\mathrm{NH}_{3}$ concentrations lasted for $1-2 \mathrm{~h}$. Otherwise, high $\mathrm{RH}$ was related to slight increases in $\mathrm{NH}_{3}$ concentrations of $1 \mathrm{ppm}$ with 1-h delay in the two houses (Figure $5 \mathrm{k}-1$ ).

In winter, inverse relationships between $\mathrm{RHs}$ and $\mathrm{NH}_{3}$ concentrations were observed at the current time and a few subsequent hours in the two houses, when the reference was the $\mathrm{NH}_{3}$ concentration at the $\mathrm{RH}$ of $70 \%$ (Figure $2 \mathrm{H}-\mathrm{A}$ winter $\mathrm{RH}$ and Figure $3 \mathrm{H}-\mathrm{B}$ winter $\mathrm{RH}$ ). The influences of lower $\mathrm{RH}$ were significant only in $\mathrm{H}-\mathrm{B}$, where a slight increase of $\mathrm{NH}_{3}$ concentration by $1 \mathrm{ppm}$ was observed and lasted for $1 \mathrm{~h}$ (Figure $6 \mathrm{i}$ j). Increases in the outdoor RH from $70 \%$ to $95 \%$ led to significant rises of $\mathrm{NH}_{3}$ concentrations (about $2 \mathrm{ppm}$ ) in both houses with time lags of $1 \mathrm{~h}$ (Figure $6 \mathrm{k}-1$ ). Higher concentrations lingered for more than $5 \mathrm{~h}$. These results suggested that the outdoor $\mathrm{RH}$ indirectly affected the $\mathrm{NH}_{3}$ concentrations in high-rise layer houses in winter.

\subsection{Application of DLNM in Agricultural Air Quality Mo- deling}

Though this paper represented the first application of DLNM to agricultural air quality modeling, the use of the new nonlinear modeling method along both dimensions of variable and lag uncovered and quantified the most influential factors and their relationships with $\mathrm{NH}_{3}$ concentrations in layer houses. This study is helpful not only for understanding the dynamics of pollutants in animal houses, but also for modeling air quality by the influencing period of a specific variable. It can also play a potential role in animal house management by predicting incoming peak concentrations of aerial pollutants in the houses.

One possible limitation of this study was due to the lack of commonly recognized procedures for DLNM model selection and parameter optimization. In this study, the distribution, deviance and autocorrelation plot of residuals were checked as suggested by Guo et al. (2011), based on the incorporated regression structure of the DLNM. More general model selection methods, like AIC, were also used as a parameter optimiza- tion criterion. The final model was selected based on easier interprettation, following the recommendations of Armstrong (2006) and Gasparrini et al. (2010). These improvements helped the interpretation of the modeling results.

On the other hand, the unique properties of the continuous monitoring dataset of agricultural air pollutant introduced more complexity of the model development. The variables in the model were selected based on the basic model selection procedures for regression and previous knowledge of the dynamics of air pollutant in the high-rise layer houses. However, the model was developed based on two specific houses in the same location, and therefore, it is difficult to make more general conclusions about the $\mathrm{NH}_{3}$ dynamics in other high-rise layer houses.

In the future, more applications of DLNM to the indoor air quality in the high-rise layer houses should be carried out with the expectations of general conclusions drawn from more simplified models, of which the application scopes could be broadened to other livestock and poultry houses of the same type.

\section{Conclusions}

The following conclusions were drawn in this study:

1. Although still with some limitations, the DLNM applied to mine a comprehensive dataset of air quality in two specific high-rise layer houses uncovered the three most influential factors and their non-linear lagged effects on indoor $\mathrm{NH}_{3}$ concentrations. 
2. Ventilation played a primary role in affecting the indoor $\mathrm{NH}_{3}$ concentrations and driving the indoor dynamics. Its effects had no observable delay and lasted for hours based on the two-year data and the summer data subsets. However, in winter, the ventilation rate within the actual operational range was too low to effectively reduce the $\mathrm{NH}_{3}$ concentrations.

3. Lowing outdoor $\mathrm{T}$ decreased $\mathrm{NH}_{3}$ concentrations with a long lag of $9 \mathrm{~h}$ in both houses based on the two-year dataset. The effects of outdoor $\mathrm{T}$ were significant in summer but not observable for both houses in winter.

4. The effects of outdoor RH were mostly observable in winter, when other influencing factors were not playing an overwhelming role in the indoor $\mathrm{NH}_{3}$ dynamics. Increasing $\mathrm{RH}$ in winter was related to increased $\mathrm{NH}_{3}$ concentrations with the lag time of about $1 \mathrm{~h}$.

5. Seasonal differences of the delayed influences were demonstrated for all three influencing factors in this study, suggesting a necessity to consider the seasonality when performing empirical modeling or investigating how these influencing factors affect $\mathrm{NH}_{3}$ in layer houses.

6. More research is needed to exploit the potential of DLNM and apply it to the dynamics of pollutants in other livestock and poultry houses.

Acknowledgement: This research was funded by the Agricultural Research Program Assistantship, College of Agriculture, Purdue University and based on the NAEMS data. Dr. Antonio Gasparrini from London School of Hygiene \& Tropical Medicine, London, England and Dr. Yuming Guo from the University of Queensland, Brisbane, Australia provided important advice for the modeling.

\section{References}

Armstrong, B. (2006). Models for the relationship between ambient temperature and daily mortality. Epidemiology, 17(6), 624-631. http://dx.doi.org/10.1097/01.ede.0000239732.50999.8f

Battista, T.D., and Visini, G. (2006). The environmental long-memory space-time series prediction. J. Environ. Inf., 7(1), 48-55. http:// dx.doi.org/10.3808/jei.200600066

Behera, S.N., Betha, R., and Balasubramanian, R. (2013). Insights into chemical coupling among acidic gases, ammonia and secondary inorganic aerosols. Aerosol Air Qual. Res., 13(4), 1282-1296. http:// dx.doi.org/10.4209/aaqr.2012.11.0328

Bjerg, B., Norton, T., Banhazi, T., Zhang, G., Bartzanas, T., Liberati, P., Cascone, G., Lee, I.B., and Marucci, A. (2013). Modelling of ammonia emissions from naturally ventilated livestock buildings. Part 1: Ammonia release modelling. Biosyst. Eng., 116(3), 232-245. http://dx.doi.org/10.1016/j.biosystemseng.2013.08.001

Blanes-Vidal, V., Nadimi, E.S., Ellermann, T., Andersen, H.V. and Løfstrøm, P. (2012). Perceived annoyance from environmental odors and association with atmospheric ammonia levels in nonurban residential communities: a cross-sectional study. Environ. Health., 11(1), 1-10. http://dx.doi.org/10.1186/1476-069X-11-27

Calvet, S., Cambra-López, M., Blanes-Vidal, V., Estellés, F., and Torres, A.G. (2010). Ventilation rates in mechanically-ventilated commercial poultry buildings in Southern Europe: Measurement system development and uncertainty analysis. Biosyst. Eng., 106(4), 423-432. http://dx.doi.org/10.1016/j.biosystemseng.2010.05.006

Dawkins, M.S., Donnelly, C.A., and Jones, T.A. (2004). Chicken welfare is influenced more by housing conditions than by stocking density. Nature, 427(6972), 342-344. http://dx.doi.org/10.1038/ nature 02226
Elliott, H.A., and Collins, N.E. (1982). Factors affecting ammonia release in broiler houses. Trans. ASAE, 25(2), 413-418. http://dx. doi.org/10.13031/2013.33545

Elzing, A., and Monteny, G.J. (1997). Modeling and experimental determination of ammonia emissions rates from a scale model dairycow house. Trans. ASAE, 40(3), 721-726. http://dx.doi.org/10. $13031 / 2013.21302$

Gasparrini, A. (2011). Distributed lag linear and non-linear models in R: the package dlnm. J. Stat. Softw., 43(8), 1-20. http://dx.doi.org/ 10.18637/jss.v043.i08

Gasparrini, A., Armstrong, B., and Kenward, M. (2010). Distributed lag non-linear models. Stat. Med., 29(21), 2224-2234. http:/ /dx.doi.org/10.1002/sim.3940

Groot Koerkamp, P.W.G. (1994). Review on emissions of ammonia from housing systems for laying hens in relation to sources, processes, building design and manure handling. J. Agric. Eng. Res., 59(2), 73-87. http://dx.doi.org/10.1006/jaer.1994.1065

Groot Koerkamp, P.W.G., Metz, J.H.M., Uenk, G.H., Phillips, V.R., Holden, M.R., Sneath, R.W., Short, J.L., White, R.P., Hartung, J., Seedorf, J., Schroder, M., Linkert, K.H., Pedersen, S., Takai, H., Johnsen, J.O., and Wathes, C.M. (1998). Concentrations and emissions of ammonia in livestock buildings in Northern Europe. $J$. Agric. Eng. Res., 70(1), 79-95. http://dx.doi.org/10.1006/jaer.1998. 0275

Guo, Y.M., Barnett, A.G., Zhang, Y.S., Tong, S.L., Yu, W.W., and Pan, X.C. (2010). The short-term effect of air pollution on cardiovascular mortality in Tianjin, China: Comparison of time series and casecrossover analyses. Sci. Total Environ., 409(2), 300-306. http:// dx.doi.org/10.1016/j.scitotenv.2010.10.013

Guo, Y.M., Barnett, A.G., Pan, X.C., Yu, W.W., and Tong, S.L. (2011). The impacts of temperature 4 on mortality in Tianjin, China: a casecrossover design with a distributed lag nonlinear model. Environ. Health Perspect., 119(12), 1719-1725. http://dx.doi.org/10.1289/ ehp. 1103598

Hallquist, M. et al. (2009). The formation, properties and impact of secondary organic aerosol: current and emerging issues. Atmos. Chem. and Phys., 9(14), 5155-5236. http://dx.doi.org/10.5194/acp9-5155-2009

Huang, B., Xiong, D., and Li, H., (2004). An integrated approach to real-time environmental simulation and visulization. J. Environ. Inf., 3(1), 42-50. http://dx.doi.org/10.3808/jei.200400026

Heber, A.J., Bogan, B.W., Ni, J. Q., Lim, T.T., and Cortus, E.L. et al. (2008). The National Air Emissions Monitoring Study: overview of barn sources. Proc. of the Eighth International Livestock Environment Symposium (ILES VIII), Iguassu Falls, Brazil, 2008.

Kaasik, A., and Maasikmets, M. (2013). Concentrations of airborne particulate matter, ammonia and carbon dioxide in large scale uninsulated loose housing cowsheds in Estonia. Biosyst. Eng., 114 (3), 223-231. http://dx.doi.org/10.1016/j.biosystemseng.2013. 01.002

Kristensen, H.H., and Wathes, C.M. (2000). Ammonia and poultry welfare: a review. World Poultry Sci. J., 56(3), 235-245. http://dx. doi.org/10.1079/WPS20000018

Li, H. (2006). Ammonia emissions from manure belt laying hen houses and manure storage, Ph.D. Dissertation, Iowa State University, Ames, Iowa.

Liang, Y., Xin, H., Li, H., Wheeler, E.F., Zajaczkowski, J.L., Topper, P.A., Gates, R.S., Casey, K.D., Behrends, B.R., Burnham, D.J. and Zajaczkowski, F.J. (2005). Ammonia emissions from US laying hen houses in Iowa and Pennsylvania. Trans. ASAE, 48(5), 1927-1941. http://dx.doi.org/10.13031/2013.20002

Lin, X.J., Cortus, E.L., Zhang, R., Jiang, S., and Heber, A.J. (2012). Ammonia, hydrogen sulfide, carbon dioxide and particulate matter emissions from California high-rise layer houses. Atmos. Environ., 46, 81-91. http://dx.doi.org/10.1016/j.atmosenv.2011.10.021 
Mendes, L.B., Xin, H., and Li, H. (2012). Ammonia emissions of pullets and laying hens as affected by stocking density and manure accumulation time. Trans. ASABE, 55 (3), 1067-1075. http://dx. doi.org/10.13031/2013.41511

Miles, D.M., Branton, S.L., and Lott, B.D. (2004). Atmospheric ammonia is detrimental to the performance of modern commercial broilers. Poultry Sci., 83(10), 1650-1654. http://dx.doi.org/10.1093/ ps/83.10.1650

Miles, D.M., Rowe, D.E., and Cathcart, T.C. (2011). High litter moisture content suppresses litter ammonia volatilization. Poultry Sci., 90(7), 1397-1405. http://dx.doi.org/10.3382/ps.2010-01114

Morgan, R.J., Wood, D.J., and Heyst, B.J.V. (2014). The development of seasonal emission factors from a Canadian commercial laying hen facility. Atmos. Environ., 86, 1-8. http://dx.doi.org/10.1016/j. atmosenv.2013.12.033

Murakami, K., Hara, M., Kondo, T., and Hashimoto, Y. (2011). Increased total nitrogen content of poultry manure by decreasing water content through composting processes. Soil Sci. Plant Nutr., 57(5), 705-709. http://dx.doi.org/10.1080/00380768.2011.616856

Nahm, K.H. (2003). Evaluation of the nitrogen content in poultry manure. World Poultry Sci. J., 59(1), 77-88. http://dx.doi.org/10. 1079/WPS20030004

Ni, J. Q., Diehl, C.A., Lim, T.T., Bogan, B.W., Chen, L., Chai, L., and Heber, A.J. (2010). National Air Emissions Monitoring Study: Emissions Data from Two High-Rise Layer Houses in Indiana - Site IN2H, Purdue University, West Lafayette, pp. 330.

Ni, J. Q., Cortus, E.L., and Heber, A.J. (2011). Improving ammonia emission modeling and inventories by data mining and intelligent interpretation of the national air emission monitoring study database. Atmosphere, 2(2), 110-128. http://dx.doi.org/10.3390/atmos20201 10

Ni, J. Q., Chai, L., Chen, L., Bogan, B.W., Wang, K., Cortus, E.L., Heber, A.J., Lim, T.T., and Diehl, C.A. (2012). Characteristics of ammonia, hydrogen sulfide, carbon dioxide, and particulate matter concentrations in high-rise and manure-belt layer hen houses. Atmos. Environ., 57, 165-174. http://dx.doi.org/10.1016/j.atmosenv.2012. 04.023

Nimmermark, S., and Gustafsson, G. (2005). Influence of temperature, humidity and ventilation rate on the release of odour and ammonia in a floor housing system for laying hens. Agric. Eng. Int. CIGR J., VII (March).

Pereira, J., Fangueiro, D., Misselbrook, T.H., Chadwick, D.R., Coutinho, J., and Trindade, H. (2011). Ammonia and greenhouse gas emissions from slatted and solid floors in dairy cattle houses: a scale model study. Biosyst. Eng., 109(2), 148-157. http://dx.doi. org/10.1016/j.biosystemseng.2011.02.011

Pratt, E.V., Rose, S.P., and Keeling, A.A. (2002). Effect of ambient temperature on losses of volatile nitrogen compounds from stored laying hen manure. Bioresour. Technol., 84(2), 203-205. http:// dx.doi.org/10.1016/S0960-8524(02)00011-1

Reynolds, S.J., Chao, D.Y., Thorne, P.S., Subramanian, P., Waldron, P.F., Selim, M., Whitten, P.S., and Popendorf, W.J. (1998). Field comparison of methods for evaluation of vapor/particle phase distribution of ammonia in livestock buildings. J. Agric. Saf. Health, 4(2), 81-93. http://dx.doi.org/10.13031/2013.15351

Roberts, S.A., Xin, H., Kerr, B.J., Russell, J.R., Bregendahl, and K. (2007). Effects of dietary fiber and reduced crude protein on nitrogen balance and egg production in laying hens. Poultry Sci., 86(8), 1716-1725. http://dx.doi.org/10.1093/ps/86.8.1625

Schwartz, J. (2000). The distributed lag between air pollution and daily deaths. Epidemiology, 11(3), 320-326. http://dx.doi.org/10.1097/ 00001648-200005000-00016

Sevi, A., Taibi, L., Albenzio, M., Caroprese, M., Marino, R., and Muscio, A. (2003). Ventilation effects on air quality and on the yield and quality of ewe milk in winter. J. Dairy Sci., 86(12), 3881-3890. http://dx.doi.org/10.3168/jds.S0022-0302(03)73996-4
Summers, J.D. (1993). Reducing nitrogen excretion of the laying hen by feeding lower crude protein diets. Poultry Sci., 72(8), 1473-1478. http://dx.doi.org/10.3382/ps.0721473

Sun, G., and Hoff, S.J. (2010). Prediction of indoor climate and longterm air quality using the BTA-AQP model: Part II. Overall model evaluation and application. Trans. ASABE, 53(3), 871-881. http://dx.doi.org/10.13031/2013.30070

Takai, H., Nekomoto, K., Dahl, P.J., Okamoto, E., Morita, S., and Hoshiba, S. (2002). Ammonia contents and desorption from dusts collected in livestock buildings. Agric. Eng. Int. CIGR J., IV (June),

Takai, H., Pedersen, S., Johnsen, J.O., Metz, J.H.M., Koerkamp, P.W.G.G., Uenk, G.H. et al. (1998). Concentrations and emissions of airborne dust in livestock buildings in Northern Europe. J. Agric. Eng. Res., 70(1), 59-77. http://dx.doi.org/10.1006/jaer.1997.0280

Theobald, M.R., Løfstrøm, P., Walker, J., Andersen, H.V., Pedersen, P., Vallejo, A., Sutton, M.A. (2012). An intercomparison of models used to simulate the short-range atmospheric dispersion of agricultural ammonia emissions. Environ. Model. Software, 37, 90-102. http://dx.doi.org/10.1016/j.envsoft.2012.03.005

USEPA. (2010). Agriculture - Air Monitoring: Indiana 2B and 2H Wabash County. www.epa.gov/airquality/agmonitoring/in2b.html

Vučemilo, M., Matković, K., Vinković, B., Macan, J., Varnai, V.M., Prester, L., Granić, K., and Orct, T. (2008). Effect of microclimate on the airborne dust and endotoxin concentration in a broiler house. Czech J. Anim. Sci., 53(2), 83-89.

Wang-Li, L., Li, Q.F., Chai, L., Cortus, E.L., Wang, K., Kilic, I., Bogan, B.W., Ni, J. Q., and Heber, A.J. (2013). National Air Emission Monitoring Study - Southeast layer site: Part III - Ammonia concentrations and emissions. Trans. ASABE, 56(3), 1185-1197.

Wathes, C.M., Phillips, V.R., Holden, M.R., Sneath, R.W., Short, J.L., White, R.P.P., Hartung, J., Seedorf, J., Schröder, M., Linkert, K.H., Pedersen, S., Takai, H., Johnsen, J.O., Groot Koerkamp, P.W.G., Uenk, G.H., Metz, J.H.M., Hinz, T., Caspary, V., and Linke, S. (1998). Emissions of aerial pollutants in livestock ruildings in Northern Europe: Overview of a multinational project. J. Agric. Eng. Res., 70(1), 3-9. http://dx.doi.org/10.1006/jaer.1998.0278

Weaver, W.D., and Meijerhof, R. (1991). The effect of different levels of relative humidity and air movement on litter conditions, ammonia levels, growth, and carcass quality for broiler chickens. Poultry Sci., 70(4), 746-755. http://dx.doi.org/10.3382/ps.0700746

Wei, F.X., Hu, X.F., Sa, R.N., Liu, F.Z., Li, S.Y., and Sun, Q.Y. (2014). Antioxidant capacity and meat quality of broilers exposed to differrent ambient humidity and ammonia concentrations. Genet. Mol. Res., 13(2), 3117-3127. http://dx.doi.org/10.4238/2014.April. 17.8

Wheeler, E.F., Casey, K.D., Gates, R.S., Xin, H., Zajaczkowski, J.L., Topper, P.A., Liang, Y., and Pescatore, A.J. (2006). Ammonia emissions from twelve US broiler chicken houses. Trans. ASAE, 49(5), 1495-1512. http://dx.doi.org/10.13031/2013.22042

Wu, W., Xiao, Y., Li, G., Zeng, W., Lin, H., Rutherford, S., Xu, Y., Luo, Y., Xu, X., Chu, C., and Ma, W. (2013). Temperature-mortality relationship in four subtropical Chinese cities: A time-series study using a distributed lag non-linear model. Sci. Total Environ., 449, 355-362. http://dx.doi.org/10.1016/j.scitotenv.2013.01.090

Xin, H., Gates, R.S., Green, A.R., Mitloehner, F.M., Moore, P.A., and Wathes, C.M. (2011). Environmental impacts and sustainability of egg production systems. Poultry Sci., 90(1), 263-277. http://dx. doi.org/10.3382/ps.2010-00877

Zanobetti, A., Wand, M.P., Schwartz, J., and Ryan, L.M. (2000). Generalized additive distributed lag models: quantifying mortality displacement. Biostatistics, 1(3), 279-292. http://dx.doi.org/10. 1093/biostatistics/1.3.279 